WIDER Working Paper 2018/68

\title{
Rowing against the current
}

Diversification in Africa's resource-rich economies

John Page*

June 2018

United Nations University World Institute for Development Economics Research 
Abstract: The exploitation of natural resources is a huge opportunity, but one that carries considerable risks. Relative prices in resource-exporting economies tend to push them towards economic structures dominated by the resource sector. This paper explores ways to achieve diversification in a resource-rich economy. It describes the relative price changes that accompany a resource boom and suggests policies and public investments to mitigate their impact. It explores some of the issues that influence the participation of local firms in the resource value chain and argues for broadening the options for diversification, through the development of 'industries without smokestacks' and investments in knowledge.

Keywords: diversification, knowledge, local content, natural resources, tradable services JEL classification: Q32, Q38, O25, O14, L71, F23

Acknowledgements: The comments of participants in the UNU-WIDER Authors' Workshop on Natural Resources, Industry and Structural Change in Africa are gratefully acknowledged.

*The Brookings Institution, Washington DC, USA, and UNU-WIDER, Helsinki, Finland, jmpagejr@gmail.com.

This paper has been prepared as part of a series of studies on 'Natural Resources, structural change, and industrial development in Africa' as part of a larger UNU-WIDER research project on 'Jobs, poverty and structural change in Africa'.

Copyright (C) UNU-WIDER 2018

Information and requests: publications@wider.unu.edu

ISSN 1798-7237 ISBN 978-92-9256-510-7 https://doi.org/10.35188/UNU-WIDER/2018/510-7

Typescript prepared by Gary Smith.

The United Nations University World Institute for Development Economics Research provides economic analysis and policy advice with the aim of promoting sustainable and equitable development. The Institute began operations in 1985 in Helsinki, Finland, as the first research and training centre of the United Nations University. Today it is a unique blend of think tank, research institute, and UN agency — providing a range of services from policy advice to governments as well as freely available original research.

The Institute is funded through income from an endowment fund with additional contributions to its work programme from Finland, Sweden, and the United Kingdom as well as earmarked contributions for specific projects from a variety of donors.

Katajanokanlaituri 6 B, 00160 Helsinki, Finland

The views expressed in this paper are those of the author(s), and do not necessarily reflect the views of the Institute or the United Nations University, nor the programme/project donors. 
Although precise data are not available, it is likely that Africa holds about 30 per cent of the world's reserves of minerals, oil, and gas. The exploitation of natural resources is a huge opportunity, but it also carries considerable risks. One such risk lies in the structure of resource-abundant countries themselves. Relative prices in resource-exporting economies tend to push them towards economic structures in which a high share of output is concentrated in the resource sector and non-tradable services (UNIDO 2009). Economic structure matters because greater diversity in production and exports is associated globally with more rapid and sustained economic growth (IMF 2014). Diversifying beyond the natural resource sector is, therefore, critical to sustaining development, once natural resources are depleted.

The extractive sectors in most sub-Saharan African countries have developed as enclaves, weakly linked to the rest of the national economy. Local suppliers are seldom used, and except for South Africa and Ghana, an indigenous service and supply sector for the mining industry has not developed to any significant extent (Hanlin 2011). Most countries continue to export a disproportionate share of their resources in raw form, and royalty and fiscal transfer systems have historically not yielded much benefit to the communities in which resource extraction takes place.

The African Mining Vision (AMV) adopted by African heads of state and government in 2009 focused on the mining sector's potential to help transform economies through more diversified growth, and governments in resource-abundant countries have adopted a wide range of 'local content' and 'value-addition' initiatives. Local content regulations often require resource investors to expand national employment opportunities, procure from local suppliers, open equity to local partners, and encourage technology transfer. 'Value addition' concentrates on downstream processing of the extracted resource and promotion of related industries.

This paper explores several ways to achieve structural change and diversification in a resource-rich economy. Section 2 gives a brief history of diversification efforts in Africa's major resource exporters. Section 3 describes the relative price changes that accompany a resource boom and suggests policies and public investments to mitigate their impact. Section 4 explores some of the issues that influence the participation of local firms in the resource value chain. Section 5 argues for broadening the options for diversification through the development of tradable services and agro-industries and investments in knowledge. Section 6 concludes.

\section{Diversification initiatives}

In an effort to achieve the vision of more diversified growth from natural resources, resource-rich economies across Africa are introducing requirements for local content and value addition in their policy, legislative, and regulatory frameworks for the natural resources sector. A local content requirement is a regulation that requires domestic procurement of a specified fraction of a final good or service. Usually, legislation, regulations, or mineral extraction agreements set minimum targets for employment of local staff, purchases from national suppliers of goods and services, investment in local enterprise development, and support for local economic development around extractive activities. Value-addition initiatives include efforts to develop 'beneficiation' of raw commodities and promotion of related downstream industries. 
Africa's earliest local content initiatives in the mineral, oil, and gas sectors date to the 1960s and 1970s. Increasing backward linkages from extractive companies to local manufacturers was a key component of Zambia's post-independence industrialization strategy, pursued through a combination of preferential procurement from the state-owned Zambia Consolidated Copper Mines (ZCCM) and import substitution. Strong linkages between ZCCM, its suppliers, and public research and training institutions developed during the 1980s, but during the 1990s, with the privatization of the nationally owned mines and the introduction of trade and investment liberalization measures, Zambia's manufacturing capabilities in the mining supply chain largely eroded (Fessehaie 2012). Recently, the government has again attempted to expand local content. Zambia's Mineral Resource Development Policy, 2013 and the revised Mines and Mineral Development Act, 2015 contain requirements for preferences in employment and procurement of goods and services (OECD 2017).

The Nigerian oil industry was originally the exclusive domain of the international oil companies. In 1971, the government established the National Oil Corporation to promote indigenization of the industry, but little actually changed until the turn of the century. Local content ranged from 3 to 5 per cent of the value of production from the 1970s to the 1990s (UNCTAD 2006). In 2000, commitment to the development of Nigerian expertise in oil operations and development of input suppliers was included among the criteria for award of concessions. In addition, petroleum contracts were revised to include training and local employment obligations. Local content requirements became more stringent in 2005, and by 2009 Nigeria had reached 39 per cent local content in petroleum operations (Tordo 2009). Nigeria has gradually developed some important upstream industries-particularly in fabrication and well construction-linked to the oil and natural gas value chain (Oyejide and Adewuyi 2011). Deeper forms of cooperation aimed at improving quality, delivery and reliability are evolving, including developing quality assurance systems, upgrading technology, and training labour.

The Petroleum Activity Law of 1976 assigned sole ownership of Angola's hydrocarbon resources and mining rights to the Angolan state, which manages the sector through Sonangol, the national oil company. Sonangol sees itself as an active investor in oil extraction and in forward processing along the lines of Petrobras in Brazil. It is also responsible for developing linkages to the petroleum value chain for locally owned firms. State ownership of the resource and concession rights gives the government significant bargaining power for preferential treatment of national firms in the supply of goods and services along the value chain (Morris et al. 2011). Sonangol requires that unless the price of local inputs exceeds the price of imports by more than 10 per cent, all goods and services not requiring vaguely defined 'large capital investments and specialized know-how' must be sourced from firms having more than 51 per cent of share capital owned by Angolan citizens (Teka 2011).

Ghana has a long history of gold mining, and a supplier industry linked to the mining value chain has developed gradually. First-tier suppliers include global mine construction companies, international mining equipment companies, input suppliers, and agents and distributors. Local firms are smaller first-tier and second-tier suppliers in metals and metalworking, chemicals and plastics, civil engineering, business services, and logistics. Since 2010, Ghana has introduced a series of local content policies in both mining and the oil and gas sector. Its Minerals and Mining Regulations of 2012 focused explicitly on employment and promotion of the local workforce and procurement of locally produced inputs (Morris et al. 2011). Between 2009 and 2012, employment of Ghanaian nationals in the mining sector increased by 65 per cent (ECA 2013). Companies allocate staff to identify local suppliers and build capacity, and several have introduced programmes designed to increase local procurement from communities based close to the mines. The Petroleum Local Content and Local Participation Regulations, 2013 define Ghana's expectations of local content in oil and gas. The regulations set out detailed targets for minimum 
local employment and procurement of services and goods in the oil and gas sector that gradually increase over ten years (OECD 2017).

In Tanzania, the 1997 Mineral Policy and the 2012 Mineral Act emphasized developing backward linkages to the mining sector, but failed to set out targets, incentives, or penalties, leaving policy implementation largely to voluntary compliance. In gold exploration, local content is limited to drilling services and logistics, while in gold mining it is limited to fuel, equipment repair and maintenance, and basic services. Most goods and services are imported. The limited ability of local firms to meet the quality and price standards of lead suppliers and the multinational mining companies is one reason for lack of participation in the mining value chain. Potential suppliers also face a major policy-driven disadvantage: import tariff exemptions for mining inputs have been granted to the mines but not to components imported by their domestic suppliers (ECA 2013). Major new discoveries of natural gas have further complicated Tanzania's efforts to develop linkages in the natural resources value chain. The Petroleum (Local Content) Regulations 2017 give priority to maximizing local participation in the gas sector-including in highly specialized operations-over developing linkages with other sectors. It is uncertain whether Tanzania has sufficient gas reserves to justify investing in the development of highly specialized skills or the production of goods and services of use only to the gas sector, and there is little information on local capabilities (Roe 2017; Scurfield et al. 2017).

Mozambique has identified several areas in which resource-extraction firms are required to make special efforts to increase local participation. Mining firms are obliged to have between 5 and 20 per cent of their equity held by Mozambicans. Local content requirements are set out in the Mining Law and Petroleum Law, both of 2014. These require that contracts for the procurement of goods and services give preferential treatment to 'the purchase of local goods and services when such goods and services are internationally comparable in terms of quality, availability, and quantity required and are offered at prices inclusive of taxes not higher than ten percent of the available imported goods'. The legal framework is at an early stage in terms of defining objectives and the means to achieve them. Recent regulatory reforms seek to increase the participation of Mozambicans in the mining sector gradually, without obliging firms to adhere to numerical targets, and a number of suppliers' development programmes have been instituted with varied success (OECD 2017).

South Africa has significant expertise in mining and mining-related supply industries. It has several globally competitive suppliers and has developed clusters of firms that provide world-class goods and services to the global mining industry (Kaplan 2012). Some 89 per cent of spending by mining firms is local, and the local content of exports of mining equipment is estimated at 90 per cent. South African suppliers are global leaders in a number of areas, such as underground locomotives, mining fans, and submersible pumps (ECA 2013). South Africa's Broad-Based Black Economic Empowerment Act of 2003 is a post-apartheid effort to promote local ownership among historically disadvantaged citizens. Its local content requirements include employment quotas at all levels of the firm, ownership requirements, procurement targets, mandatory expenditure on training, and suppliers' development. Mining rights holders are encouraged by the Mining Charter (2004) to procure an increasing percentage of their capital goods, consumables, and services from Black Economic Empowerment suppliers (OECD 2017).

Botswana has pursued the idea of processing uncut diamonds since the 1980s, when government pressure on De Beers led to the establishment of three cutting and polishing factories. A major opportunity to ratchet up the pressure for forward linkages came in 2005, when De Beers' 25-year mining licence was due for renewal. The government insisted that for De Beers to renew its licence it should use its considerable market power to help Botswana create a globally competitive diamond cutting and polishing industry. In 2006, the government invited some of the world's 
leading cutting and polishing companies to establish factories in Botswana. To promote the transfer of cutting and polishing skills to local citizens, the companies receive rough diamond allocations on the condition that they hire and train locals in cutting and polishing skills. The 16 factories currently in operation employ more than 3,000 people, most of whom are Botswanan citizens. Policies designed to enhance capabilities further down the value chain-for example, in jewellery manufacture and trading_-are still under development (Mbayi 2011).

Overall, progress in increasing local content and value addition has been mixed. Most countries have succeeded in introducing and enforcing requirements for the employment and gradual upskilling of nationals. Changes in mining technology, however, mean that direct employment in mining is on the decline. The hydrocarbon sector is highly capital- and skill- intensive and offers limited prospects for the employment of large numbers of national workers. These technologydriven realities make employment requirements increasingly difficult to enforce, raising questions about the primacy of the employment objective in local content legislation.

Local procurement regulations have met with limited success for several reasons, including the small size of local markets and the scarcity of small and medium enterprises capable of satisfying industry standards in the procurement of goods and services. The private sector has often been too weak to respond to local content policy initiatives (Ramdoo 2015). Poor implementation of local content development policies has also been a common problem, and in several countries programmes aimed at the resources sector lack coherence with broader economic development policies (Morris et al. 2011).

\section{Dealing with Dutch disease}

The relative price changes that occur in a resource-abundant economy make diversification into tradable goods production outside the natural resources sector difficult. During a commodity boom, the income from resource extraction increases the demand for all goods. In the case of internationally traded goods, imports can meet the increased demand, but because non-traded goods are subject to increasing marginal costs, the relative price of non-tradables tends to rise. The foreign exchange market reflects the increase in a real exchange rate appreciation, reducing the potential profitability of tradable goods-producing activities. This 'Dutch disease' tends to make the development of manufacturing and other tradable goods and services outside the minerals sector more difficult.

International competitiveness, however, is not solely determined by the exchange rate. Governments can enhance the productivity of private investments outside the natural resource sector by undertaking institutional and regulatory reforms and making public investments that lower the costs of producing tradable goods; in short, by improving the 'investment climate' (Stern 2001). The investment climate has come to be broadly and somewhat vaguely defined, but three of its key elements are particularly relevant to dealing with Dutch disease-regulation, infrastructure, and skills. Well-designed regulatory reforms, reliable electrical power, lower costs of transport, and workers better able to perform their jobs increase the potential productivity of all firms (Newman et al. 2016). Thus, governments can complement direct efforts to link domestic firms to the resource value chain with broader investments and reforms to improve the investment climate. An added benefit is that the investment climate reforms will also benefit domestic firms attempting to enter the resource value chain. 


\subsection{Regulatory reform}

Reforms that reduce regulatory compliance costs and encourage firm entry and exit can have high payoffs. Surveys of firms in resource-abundant African countries highlight a wide range of areas in which regulatory or administrative burdens raise costs and reduce competitiveness. In Uganda, for example, inadequate regulatory capacity and an unclear regulatory framework increase the regulatory burden. Senior managers of manufacturing firms spend more than 13 days each year on average dealing with government officials, and 40 per cent of the manufacturing firms surveyed complained that regulations were not interpreted consistently (Henstridge and Page 2012). In Mozambique, business regulations-and the opportunities for corruption engendered by the regulatory regime-increase firms' costs and reduce competitiveness (World Bank 2009a). In Kenya, which has recently discovered oil, almost one-third of firms ranked corruption-ranging from payments for utility hook-ups to informal payments in public procurement-among the top three problems faced. Three-quarters of Kenyan firms reported having to make payments to public officials to 'get things done', and the more often inspectors visited firms, the more likely they were to ask for informal payments (World Bank 2009b).

Reforms that encourage the entry and exit of firms can have a positive impact on productivity. In open economies, imports should provide competition in domestic markets, yet World Bank Enterprise Surveys often find that formal-sector firms in Africa do not feel pressed by competition. More than 70 per cent of African countries rank in the bottom half on the perceived intensity of local competition (World Bank 2016b). Changes to rules that make markets more open and contestable-by facilitating imports, supporting entry in production or operation, and giving all firms an opportunity to compete on common ground-can reduce concentration and the likelihood of anticompetitive practices. Building capacity to help strengthen competition authorities and increase the effectiveness of competition policy is also important.

Institutional and regulatory reforms should be undertaken soon after natural resources are discovered. This is because they may prove more difficult to initiate and sustain in resource-rich countries once resource revenues start to flow. Incumbent workers and firms benefit from lack of competition and have little incentive to support improvements in the regulatory regime. Normally, pressures for regulatory reform would come from other interest groups in society, but there is evidence that rent-seeking interests gradually make competing interest groups less successful in changing policy in resource-exporting countries (Collier and Hoeffler 2008).

\subsection{Infrastructure and skills}

The revenues that flow from natural resources open fiscal space for governments of resourceabundant economies to address two of the fundamental constraints to competitiveness in Africa: lack of infrastructure and skills. African firms pay a substantial productivity penalty because of poor infrastructure (Escribano et al. 2010). Sub-Saharan Africa lags at least 20 percentage points behind the average for low-income countries on almost all major infrastructure measures. In addition, the quality of service is low, supplies are unreliable, and disruptions are frequent and unpredictable (Newman et al. 2016). The quality of electricity service is ranked as a major problem by more than half of the firms in more than half of the African countries in the World Bank's Investment Climate Assessments. Transport comes a close second to power across the region. Road infrastructure has received little attention, as, until recently, have ports and railways.

Investments in trade-related infrastructure can make an important contribution to diversification. By reducing both the variable and fixed costs of exporting, trade facilitation increases the exports of those firms already involved in international trade, while enabling new firms to export for the first time. Global value chains in activities from manufacturing to horticulture are highly 
demanding of trade logistics. The nine resource-rich African countries have an average traderelated infrastructure (ports, rail, road, and telecommunications) ranking of 125 out of 160 countries in the World Bank Trade Logistics Index (World Bank 2016a). Seven are in the bottom third of the global distribution and four are in the bottom quintile. Public investments in power, transport, and trade logistics can boost competitiveness.

Despite significant gains in average levels of schooling, the region's workforce is the least skilled in the world (World Bank 2017). In many countries, the skills constraint is felt most strongly in more productive and export-oriented firms. Firms with at least 20 employees-those that are generating employment in growing economies - are feeling the skills shortage as well. Employers in the region are increasingly demanding workers with multiple skills. More than half of the firms surveyed as part of the School to Work Transition surveys in several African countries reported that technical, interpersonal, and higher-order cognitive skills (problem-solving and decisionmaking) are important to them. Because poor learning outcomes diminish the foundational skills of workers, improvements in quality at all levels are needed. Investments in demand-driven technical and vocational education and training, higher education, entrepreneurship, and business training programmes can spur productivity growth (World Bank 2017). In an increasingly austere aid environment, governments can use resource revenues to address the skills gap.

Unmet needs in infrastructure and skills increase pressures for spending following new discoveries, but prudent revenue management requires establishing how much public spending should increase and how much to save. Not all infrastructure and education projects will have the same impact. Careful cost-benefit analysis of infrastructure investments is essential, and governments should have a prioritized list of vetted projects ready for funding. Applying this rule is actually more complex than it appears. It is difficult to appraise the possible catalytic effect of investments in infrastructure and human capital on private investment. Nevertheless, problems with addressing externalities should not be an excuse for failure to evaluate the vast majority of investment projects. For example, rigorous assessments of the cost effectiveness of proposed skill development programmes can be undertaken. Once the overall volume of spending consistent with prudent public investment is set, the revenue that remains should be parked in investments overseas.

Because the needs in infrastructure and skills are large and the timing of revenues is uncertain, governments face strong pressures to borrow in anticipation of the arrival of resource revenues. Careful debt management is essential. In the case of Ghana, for example, the government ramped up infrastructure spending before resource revenues were in place, raising the public debt burden through sovereign borrowing. Sovereign debt generally comes with high costs and short maturities. This may adversely affect the country's ability to borrow in the future. In situations in which governments face external credit constraints, it may even make sense to use a portion of the resource windfall to repay foreign debt (van der Ploeg and Venables 2011).

\section{$4 \quad$ Linking industry to the resource}

In resource-rich countries, foreign investors are often competing to gain access to the resource. This gives an opportunity to governments to attempt to integrate local companies into the supply chains of the multinational resource-extraction firms. One widely used policy has been to require preferential local procurement, but simple rules of thumb-like domestic content legislation-are frequently ineffective. Backward linkages to input suppliers and forward linkages to processors are often a function of the age and the scale of the resource sector in the country (ECA 2013). Ghana and South Africa's relative success in integrating mineral development with the rest of the economy is due to historical circumstances. Nigeria's, Mozambique's, and Tanzania's efforts in 
building resource-based industrialization using oil and gas have not been as effective. Botswana's success in diamond cutting and polishing mainly reflects its market power in the global diamond market.

The supply chains of multinational companies (MNCs) in resource extraction generally have a pyramid structure. The multinational company will have a small number of lead subcontractors, some international and some local. Each lead subcontractor will then contract other companies to supply inputs. These are the second-tier subcontractors. Only a small number of local firms can play the lead subcontractor role in any area of activity, and the MNCs may prefer to operate almost exclusively with foreign lead subcontractors. Even where local capability is available, local suppliers may not have the opportunity to tender. For example, in 2013 the Zambian Association of Manufacturers reported that mining procurement managers in the Copperbelt were unaware of local manufacturing of roofing sheets, a significant and competitive metal fabrication industry (Fessehaie et al. 2016).

Governments and the public, on the other hand, frequently have inflated expectations of how many domestic firms can be integrated into the resource-related value chain. There is a tendency for policy makers to focus upstream on opportunities for local engineering, fabrication, assembly, and construction firms to participate in the new extractive investments. Downstream, the emphasis tends to be on further processing of the resource. Ghana's industrial development strategy, for example, calls for the establishment of new industries such as petrochemicals, fertilizer, and liquefied petroleum gas (LPG) cylinder production linked to its oil and gas industry. This is an overly narrow view of what kinds of firms can benefit from the resource boom and runs the risk of concentrating on capital-intensive sectors that generate little employment. It also diverts attention from other opportunities, some as mundane as cleaning, catering, security, and personnel transport, which are often locally outsourced in African resource-producing countries (Morris et al. 2012).

\subsection{Building a public-private partnership}

Integration of local firms into the resource value chain depends on addressing the priorities and concerns of both the MNCs and the government. This is a more complex undertaking than legislating or regulating local content. It depends on the ability of government and industry to develop an effective public-private partnership. Most major resource-extraction multinationals devote considerable resources to the management of local content development and systematically analyse patterns of local procurement with a view to improving their processes. A major Zambian mining MNC, for example, has created a local business development programme that focuses on improving delivery time, increasing access to finance, providing skills and technical expertise, and developing quality assurance systems (ECA 2013).

From the public-sector side, well-designed institutions to negotiate and manage local participation are critical to success. Sutton (2012) advocates creating an institutional focal point-located within the office of the head of state or government - to act as the broker between the MNCs and domestic firms. ${ }^{1}$ The agency should have deep familiarity with the range of capabilities of domestic companies and be staffed with professionals with the ability to deal on equal terms with executives in the procurement divisions of the MNCs. Its primary functions are to propose realistic targets for integrating local firms into each area of operation and to take the lead role in establishing qualification schemes for domestic firms to achieve 'approved vendor' status, including the design

\footnotetext{
${ }^{1}$ He calls it a 'Local Content Unit (LCU)'.
} 
of appropriate training programmes. Some staff should have industry experience, while others require a public-sector background to facilitate coordination across government agencies.

A high-level champion is crucial to success. Because the agency is responsible for leading negotiations with the MNCs, it needs to have, and be seen to have, support at the highest political level. A senior sponsor in government can also be useful in resolving conflicts among the multiple interests that are engaged in local content issues. The programme and the agency should be subject to periodic reviews and evaluated against observable outcomes-for example, the rate of growth of jobs. It should also be subject to a sunset clause: requiring that a programme expire unless a review recommends that it be extended places the burden on advocates to show why it remains relevant (Page and Tarp 2017).

\subsection{Improving coordination and reducing complexity}

Efforts aimed at building local capabilities are crosscutting and require balancing different, sometimes conflicting, priorities. Because the development of local content is part of the overall planning process, a clear link to the Planning Ministry is needed. One benefit of having an institutional focal point and a high-level champion in government is improved incentives for coordinated behaviour across ministries. Lack of coordination among different government entities and levels of government may result in conflicting regulations, increased administrative costs, delays in project execution, and in some cases may create an incentive for rent-seeking behaviour. In Angola, for example, industrial policy is the responsibility of the Ministry of Industry, while policy towards the oil sector (including backward linkages) is the responsibility of the Ministry of Petroleum and Sonangol. There are no joint-working arrangements in policy design and implementation.

In many resource-rich countries, local content regulations are complex, adding to the administrative costs of firms and exceeding the capacity of the regulators. In Ghana and South Africa, resource companies appear to have been sending large volumes of documents to regulatory bodies, knowing that the capacity of these bodies to read and digest them is limited (ECA 2013). Especially for small businesses, assimilating and complying with complex administrative and/or technical rules can create an unreasonable burden. One attractive feature of creating a focal agency is that it can reduce complexity by concentrating reporting requirements on specific constraints identified by the MNCs and the local private sector.

\subsection{Training}

Because initially only a small number of local firms may be able to play a role in any area of activity along the resource value chain, training programmes for potential supplying firms - covering both technical and business management subjects - are needed. The objective of training is to raise the capabilities of local firms to the minimum level required to allow them to become 'approved vendors' and enter the MNC value chains. For training to succeed, the government and the resource-extraction companies need to agree on the design of training, and on the qualification process through which a firm achieves approved vendor status. Supplying training without buy-in by both parties is unlikely to lead to good outcomes. Ghana, for example, established an Enterprise Development Centre (EDC) to enhance the capacity of indigenous firms to participate in the oil and gas industry, but only a few well-established medium- to large-scale Ghanaian enterprises have been able to take advantage of the opportunities provided (Ablo 2015).

Randomized experiments suggest that management training at the firm level is a potential channel for building the capabilities of local firms (Bloom et al. 2013), but they also raise some red flags. The results of most training programmes targeted at micro, small, and medium enterprises 
(MSMEs) have been disappointing (McKenzie and Woodruff 2012). The challenge is to identify firms that can benefit most from training. These are likely to be higher-capability firms (Otsuka and Sonobe 2014). If firms have failed to adopt good management practices out of ignorance, training programmes in basic management, like inventory and quality control, targeted to highercapability firms offer a potentially substantial payoff in terms of increased productivity. Unless incentives are right, however, training may not achieve its full potential. When firms lack competitive pressure, they often fail to see the need to improve performance (Bloom et al. 2013).

Because the number of domestic firms hoping to benefit from a resource boom is potentially large, choosing those eligible for training must balance selectivity against effectiveness. Narrow or opaque selection criteria may encourage rent seeking, while broad criteria may result in attempting to train too many low-capability firms. This can be addressed by setting up a process that allows any local firm to apply but specifies in advance a set of criteria that will be used in selecting applicants. Oversight of the programme, ideally by an independent watchdog organization composed of public-sector, private-sector, and civil-society representatives with a reputation for probity and public disclosure of their findings can help to diminish concerns of abuse.

\section{$5 \quad$ Widening the options}

Although new discoveries of natural resources make the process of diversification more challenging, they also offer new opportunities. This section explores two. The first is to broaden the perspective on diversification from a focus on manufacturing to include other tradable goods and services. The second is to develop knowledge, either linked to the resource itself or in areas in which a resource-abundant economy may have geographical or other location-specific sources of comparative advantage.

\subsection{Industries without smokestacks}

As Africa enters its next phase of development, it confronts a global economy substantially different from previous 'late industrializers'. Our understanding of industry is changing. Today, new technologies have spawned a growing number of services and agro-industries-including horticulture - that share many characteristics with manufacturing. They are tradable, have high value added per worker, and can absorb large numbers of workers. Like manufacturing, these 'industries without smokestacks' benefit from technological change, productivity growth, scale, and agglomeration economies. ${ }^{2}$ They may provide an alternative path towards diversification.

Since the 1980s, global trade in services has grown faster than merchandise trade. Modern service exports (computer and information services, financial services, business services, and communication) are growing especially rapidly. In 2014, the tourism industry provided an estimated 277 million jobs and accounted for about 9.8 per cent of global gross domestic product (GDP) (Daly and Gereffi 2018). In horticulture, a logistics-based revolution has occurred: once efficient logistics are in place, countries with suitable agroecological conditions are able to produce high-value products, such as cut flowers and fresh vegetables, which formerly needed to be grown near their point of consumption. As a result, horticultural exports increased to around 12 per cent of global agricultural exports in 2014 (Fukase and Martin 2018).

\footnotetext{
${ }^{2}$ See Ghani and Kharas (2010).
} 
Where the service sector has the characteristics attributed to manufacturing-strong linkages, productivity growth, and technological innovations - it can act as an engine of structural change. ${ }^{3}$ Several modern service sectors - such as information and communications technology (ICT) services, transport, and logistics - have become leading sectors in a number of countries (Lavopa 2015; Lavopa and Szirmai 2014). In tourism and horticulture, leading firms connect customers and service providers along global value chains that push suppliers to upgrade product quality, respond to changing tastes, and reduce costs. Participation in global value chains is a significant driver of labour productivity. An increase of 10 per cent in the level of global value chain participation increased average productivity by close to 1.7 per cent (Constantinescu et al. 2017).

Chile, the world's leading copper producer, was a pioneer in diversifying through industries without smokestacks. Its abundant lakes and rivers are ideal for the cultivation of salmon, and its climate and topography are well suited to the production of wine. By 2000, Chile had become the world's second-largest producer of Atlantic salmon and the world's fourth largest exporter of wine. African resource exporters may also find opportunities to diversify into horticulture, agro-industry, or tradable services, where geography or other endowments provide a comparative advantage.

Because industries without smokestacks share many firm characteristics with smokestack industries - tradability foremost among them-it is possible to develop a diversification strategy that applies broadly to manufacturing, tradable services, agro-industry, and horticulture. The strategy has two components-investment climate reforms and an 'export push'. Investment climate reforms have the potential to raise the productivity of firms in industries without smokestacks, as well as in manufacturing. ${ }^{4}$ The regulatory regime in telecommunications is vital to IT-enabled services. Tourism is strongly dependent on how the air transport system is regulated and is sensitive to the behaviour of public officials ranging from immigration inspectors to the police. Horticultural exports are perishable and particularly vulnerable to delays in shipping caused by inefficient or corrupt inspection procedures at airports. Because productivity in services has an important impact on productivity levels across the economy, encouraging a competitive environment is essential.

Lack of infrastructure and skills limits the ability to diversify. Trade-related infrastructure directly affects the competitiveness of manufactured and horticultural exports. High-speed data transmission is critical to exporting a wide range of services and especially to IT-intensive exports. Most African countries lack adequate backbone IT infrastructure because they went straight to mobile networks without investing in connectivity first. Tourist-related infrastructure is a necessary condition for fully leveraging the region's tourism potential (Daly and Gereffi 2018). In Kenya, attempts to expand the IT-enabled services industry rapidly have encountered constraints due to a lack of software development and project management skills. Senegal's rank among the top 50 potential suppliers of outsourcing services has fallen significantly in the last five years due to weakness in the quality and quantity of human resources (English 2018). Management, organization, communication, and computer skills are critical for tourism development (Daly and Gereffi 2018).

For most countries in Africa, regional and global export markets represent the best option for rapid growth of manufacturing and industries without smokestacks. Exports permit firms to realize economies of scale, and in low-income countries the act of exporting raises firm-level productivity

\footnotetext{
${ }^{3}$ See, for example, Ghani and O'Connell (2014), Szirmai and Verspagen (2015), and Tregenna (2015).

${ }^{4}$ It is important to keep in mind that each activity has some unique characteristics that imply generic, and 'one size fits all' policy-making may be ineffective. Complementary sector-specific public actions may also be required.
} 
through learning (Harrison and Rodriguez-Clare 2010). Because individual firms in resourceabundant economies face high costs of entering export markets, governments need to develop an 'export push' - a coherent package of trade policies, public investments, regulatory reforms, and institutional changes to support new exporters. A critical component of the export push is prudent macroeconomic management of the resource windfall. While some appreciation of the exchange rate is unavoidable, public expenditures must be managed to reduce excessive upward pressure. The structure of protection plays an important role in ensuring that exporting is as attractive as producing for the local market. Duty drawback, tariff exemption, and VAT reimbursement schemes are often complex and poorly administered; these can be reformed. Investments and institutional reforms to improve trade logistics are essential, including institutional reforms at the regional level to improve transnational transport corridors. Market structure in the transport sector and inappropriate regulations can also impede exports, and should be addressed

\subsection{Investing in knowledge}

In addition to investments in general production skills, there is a strong case for attempting to build specialist knowledge linked to the extractive industries themselves. The South African mining supplier industry has developed globally competitive capabilities based on serving the domestic mining industry. South Africa is a world leader in a wide range of mining equipment products, including spirals for washing coal, water pumps, underground locomotives, and ventilation. The area in which South African expertise is particularly advanced is in turnkey deep-level mine design and operation. At the time oil was discovered, Norway had no expertise in the oil industry. The Norwegian government invested in building specialist knowledge about deep-sea oil exploration through its universities. Now, Norway's knowledge-based oil service industry is a major source of income in its own right. Qatar's expertise is in dealing with the environmental consequences of oil spills. Qatari companies have developed a global reputation that has involved them is such highprofile containment and clean-up operations as the BP spill in the Gulf of Mexico. Initially, resource-abundant economies should attempt to strengthen the geology and engineering departments of universities, with the goal of developing more technically qualified staff and, perhaps, a services export industry. A recent public-private partnership between the Jubilee Partners and Takoradi Polytechnic in Ghana, the Jubilee Technical Training Center (JTTC), is an example. The first batch of petroleum engineering trainees graduated in 2014.

Resource exporters may also have the opportunity to use knowledge for diversification into industries without smokestacks. IT-enabled services, horticulture, and tourism all depend on knowledge of potential markets and production. In Chile, the main drivers of growth in both salmon and wine were investments in the generation and diffusion of production knowledge across firms. The initiative was led by an innovative public-private partnership, the Fundación Chile, and eventually involved private firms, government at all levels, universities, and specialist research institutes (Kjöllerström and Dallto 2007). Similar three-way partnerships with the private sector, universities, and specialist research institutions can be developed around tradable services or agroindustries in which resource-abundant economies have location-specific comparative advantage.

\section{Conclusions}

Discoveries of oil, gas, and minerals represent an unparalleled opportunity for Africa's resourceabundant economies, but one accompanied by substantial risks. For the typical resource-rich economy in Africa, natural resources are not sufficiently abundant to ignore economic structure, and diversification is important. It helps to establish the basis for long-term growth and development once the resource has been depleted. The relative price changes that occur in resource-exporting economies - symptoms of Dutch disease-place them at a disadvantage with respect to diversification. The public revenues accruing to governments from resource 
extraction - together with complementary institutional and policy reforms - can be used to offset this disadvantage through improvements in the investment climate. Institutional and regulatory reforms and investments in infrastructure and skills can help to raise the productivity of firms outside of the resource sector.

Beyond investments in institutions, infrastructure, and skills, African governments have a range of options for diversification. The common approach is to use the presence of the resource to acquire firm capabilities from global resource investors. Because they control access to the resource, governments can seek to integrate local suppliers into the resource value chain. This is closest in spirit to the concept of local content held by most African policy makers, but it is not a trivial task. It requires a deep understanding of the current capabilities of domestic firms and a strong commitment to develop the institutional framework needed to expand them.

Governments can widen the options for diversification to include 'industries without smokestacks'. Agro-industry, tourism, and tradable services may prove less vulnerable to appreciation of the real exchange rate than task-based manufactured exports. And, because they share many characteristics in common with manufacturing, a common diversification strategy based on investment climate reforms and an export push can be effective. Governments can also use resource revenues to develop specialized knowledge, linked either to the resource itself or in industries with geographical or other country-specific sources of comparative advantage to develop non-traditional exports. 


\section{References}

Ablo, A. (2015). 'Local Content and Participation in Ghana's Oil and Gas Industry: Can Enterprise Development Make a Difference?'. The Extractive Industries and Society, 2(2): 320-27.

Bloom, N., B. Eifert, A. Mahajan, D. McKenzie, and J. Roberts (2013). 'Does Management Matter? Evidence from India'. Quarterly Journal of Economics, 128(1): 1-51.

Collier, P. and A. Hoeffler (2008). 'Testing the Neo-Con Agenda: Democracy and Natural Resource Rents'. European Economic Review, 53(3): 293-308.

Constantinescu, C., A. Mattoo, and M. Ruta (2017). 'Does Vertical Specialization Increase Productivity?' Policy Research Working Paper 7978. Washington, DC: World Bank.

Daly, J., and G. Gereffi (2018). 'Trade in Services: Opening Markets to Create Opportunities'. In R. Newfarmer, J. Page, and F. Tarp (eds), Industries Without Smokestacks: Industrialization in Africa Reconsidered. Oxford: Oxford University Press.

ECA (2013). Making the Most of Africa's Commodities: Industrializing for Growth, Jobs and Economic Transformation. Addis Ababa: UNECA.

English, P. (2018). 'Senegal: A Service Economy in Need of a Boost'. In R. Newfarmer, J. Page, and F. Tarp (eds), Industries Without Smokestacks: Industrialization in Africa Reconsidered. Oxford: Oxford University Press.

Escribano, A., J.L. Guasch, and J. Pena. (2010). 'Assessing the Impact of Infrastructure Quality on Firm Productivity in Africa: Cross-Country Comparisons Based on Investment Climate Surveys from 1999 to 2005’. Policy Research Working Paper 5191. Washington, DC: World Bank.

Fessehaie, J. (2012). 'What Determines the Breadth and Depth of Zambia's Backward Linkages to Copper Mining? The Role of Public Policy and Value Chain Dynamics'. Resources Policy, 37(4): 443-51.

Fessehaie, J., Z. Rustomjee, and L. Kaziboni (2016). 'Can Mining Promote Industrialization? A Comparative Analysis of Policy Frameworks in Three Southern African Countries'. WIDER Working Paper 2016/83. Helsinki: UNU-WIDER.

Fukase, E., and W. Martin (2018). 'Agro-Processing and Horticultural Exports from Africa'. In R. Newfarmer, J. Page, and F. Tarp (eds), Industries Without Smokestacks: Industrialization in Africa Reconsidered.Oxford: Oxford University Press.

Ghani, E., and H. Kharas (2010). 'The Service Revolution in South Asia: An Overview'. In E. Ghani (ed.), The Service Revolution in South Asia. Oxford: Oxford University Press.

Ghani, E., and S.D. O'Connell (2014). 'Can Service be a Growth Escalator in Low Income Countries?’. Policy Research Working Paper 6971. Washington, DC: World Bank.

Hanlin, C. (2011). 'The Drive to Increase Local Procurement in the Mining Sector in Africa: Myth or Reality?'. MMCP Working Paper 4. Cape Town: University of Cape Town and Open University.

Harrison, A., and A. Rodriguez-Clare (2010). 'Foreign Investment, and Industrial Policy for Developing Countries'. In D. Rodrik and M. Rosenzweig (eds), Handbook of Development Economics, vol. 5. Amsterdam: North-Holland.

Henstridge, M., and J. Page (2012). 'Managing a Modest Boom: Oil in Uganda'. OxCarre Research Paper 2/6. Oxford: Oxford Centre for the Study of Resource Rich Economies. 
IMF (2014). 'Sustaining Long-Run Growth and Macroeconomic Stability in Low Income Countries: The Role of Structural Transformation and Diversification'. IMF Policy Paper. Washington, DC: IMF.

Kaplan, D. (2012). 'South African Mining Equipment and Specialist Services: Technological Capacity, Export Performance and Policy'. Resources Policy, 37(4): 425-33.

Kjollerstrom, M., and K. Dallto (2007). 'Natural Resource-Based Industries: Prospects for Africa's Agriculture'. In United Nations Department of Economic and Social Affairs (ed.), Industrial Development for the 21st Century: Sustainable Development Perspectives. New York, NY: United Nations.

Lavopa, A. (2015). 'Technology-Driven Structural Change and Inclusiveness: The Role of Manufacturing. Inclusive and Sustainable Development'. Working Paper 14/2015. Vienna: United Nations Industrial Development Organization.

Lavopa, A., and A. Szirmai (2014). 'Structural Modernization and Development Traps: An Empirical Approach'. UNU-MERIT Working Paper 2014/76. Maastricht: United Nations University, Maastricht Economic and Social Research Institute on Innovation and Technology.

Mbayi, L. (2011). 'Linkages in Botswana's Diamond Cutting and Polishing Industry'. MMCP Discussion Paper 6. Cape Town: University of Cape Town and Open University.

McKenzie, D., and C. Woodruff (2012). What Are We Learning from Business Training and Entrepreneurship Evaluations Around the Developing World?'. Policy Research Working Paper 6202. Washington, DC: World Bank.

Morris, M., R. Kaplinsky, and D. Kaplan (2011). 'Commodities and Linkages: Industrialisation in Sub Saharan Africa'. MMCP Discussion Paper 13. Cape Town: University of Cape Town and Open University.

Newman, C., J. Page, J. Rand, A. Shemeles, M. Soderbom, and F. Tarp (2016). Made in Africa: Learning to Compete in Industry. Washington, DC: Brookings Institution Press.

OECD (2017). Local Content Policies in Minerals: Exporting Countries-Case Studies. Paris: OECD.

Otsuka, K., and T. Sonobe (2014). Cluster-Based Industrial Development: KAIZEN Management for MSE Growth in Developing Countries. New York, NY: Palgrave Macmillan.

Oyejide, T.A., and A.O. Adewuyi (2011). 'Enhancing Linkages of Oil and Gas Industry in the Nigerian Economy’. MMCP Discussion Paper 8. Milton Keynes: Open University.

Page, J., and F. Tarp (2017). The Practice of Industrial Policy: Government-Business Coordination in Africa and East Asia. Oxford: Oxford University Press.

Ramdoo, I. (2015). 'Resource-Based Industrialization in Africa: Optimising Linkages and Value Chains in the Extractive Sector'. ECPDM Discussion Paper 179. Maastricht: European Centre for Development Policy Management.

Roe, A. (2017). 'Tanzania: From Mining to Oil and Gas-Structural Change or Just Big Numbers?'. WIDER Working Paper 2017/175. Helsinki: UNU-WIDER.

Scurfield, T., N. Woodroffe, and S. Olan'g (2017). Localizing Tanzania's Gas Sector: Determining Optimal Policies for an Emerging Producer. London: Natural Resources Governance Institute.

Stern, N. (2001). A Strategy for Development. Beijing: China People’s University.

Sutton, J. (2012). Competing in Capabilities: The Globalization Process. Oxford: Oxford University Press. 
Szirmai, A., and B. Verspagen. (2015). 'Manufacturing and Economic Growth in Developing Countries 1950-2005'. Structural Change and Economic Dynamics, 34: 46-59

Teka, Z. (2011). 'Backward Linkages in the Manufacturing Sector in the Oil and Gas Value Chain in Angola'. MMCP Discussion Paper 11. Cape Town: University of Cape Town and Open University.

Tordo, S. (2009). 'Exploration and Production Rights: Allocation Strategies and Design Issues'. Working Paper 179. Washington, DC: World Bank.

Tregenna, F. (2015). 'Deindustrialisation, Structural Change and Sustainable Economic Growth: Inclusive and Sustainable Industrial Development'. Working Paper 02/2015. Vienna: United Nations Industrial Development Organization.

UNCTAD (2006). Creating Local Linkages by Empowering Indigenous Entrepreneurs: African Oil and Gas Services Sector Survey, Volume 1-Nigeria. Geneva: UNCTAD.

UNIDO. (2009). Industrial Development Report, 2009. Geneva: United Nations Industrial Development Organization.

van der Ploeg, F. and A.J. Venables (2011). 'Harnessing Windfall Revenues: Optimal Policies for Resource-Rich Developing Economies'. Economic Journal, 121(551): 1-30.

World Bank (2009a). Investment Climate Assessment of Mozambique. Washington, DC: World Bank.

World Bank (2009b). An Assessment of the Investment Climate in Kenya. Washington, DC: World Bank.

World Bank (2016a). Connecting to Compete, 2016. Washington, DC: World Bank.

World Bank (2016b). Breaking Down Barriers: Unlocking Africa's Potential through Vigorous Competition Policy. Washington, DC: World Bank.

World Bank (2017). Africa's Pulse, vol. 16. Washington, DC: World Bank. 